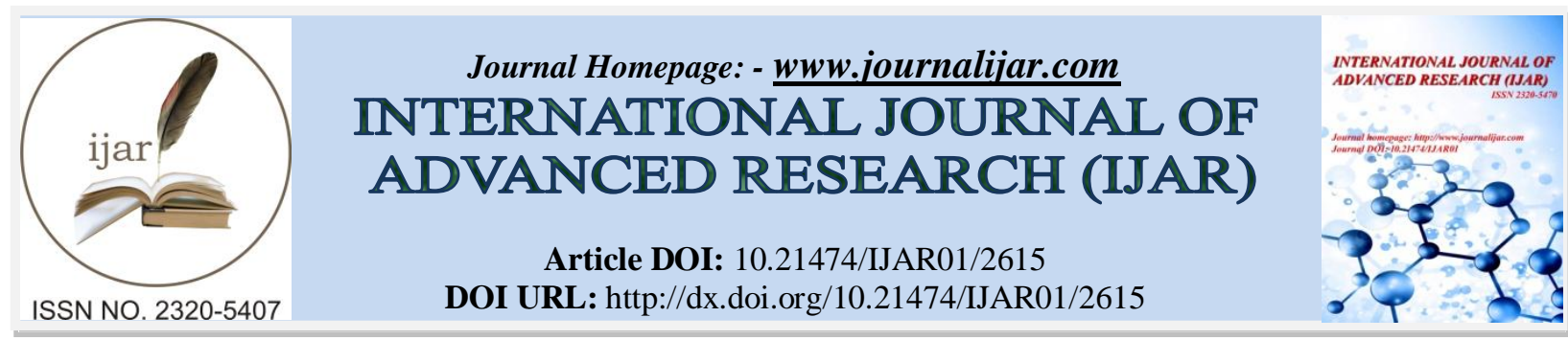

RESEARCH ARTICLE

\title{
NEED ASSESSMENT OF SPECIFIC COURSES IN TEACHING ENGLISH LANGUAGE: STUDY OF HIGHER INSTITUTIONS IN KARACHI, PAKISTAN.
}

\author{
Dr.Anila Fatima Shakil, Dr.Waqar-un-Nisa Faizi and Dr. Rabia A. Karim.
}

\section{Manuscript Info}

Manuscript History

Received: 30 October 2016

Final Accepted: 29 November 2016

Published: December 2016

Key words:-

Specific Courses - Language - ELT

\section{Abstract}

This article describes the results from a survey method research study that investigated the perceptions of participants within specific courses in the English language teaching field (ELT) in Pakistan. The study participants were students and teachers (trained and untrained) within government colleges for women. In total, 100 respondents were selected on the basis of simple random sampling. The ideas and views of the female students and teachers were solicited with regard to the importance of specific courses in the ELT, and from these, a questionnaire was developed. Correlation was used for analyzing the data. The results revealed the need for specific training courses the teaching the English language.

Copy Right, IJAR, 2016,. All rights reserved.

\section{Introduction:-}

Language is the means through which we express our feelings and ideas and communicate with others in a systematic manner. According to Mooney (2010), there is a growing realization that the basis of knowledge in linguistics is found in the speechlanguage as it is used by the members of a social order in their daily life. Language is the vehicle of communication which is employed to argue with families, joke with friends, and also deceive enemies. Language not only distinguishes humans from all other beings but also is a key to progress in various fields, andit plays a vital role in the progress and growth of any nation.

Deborah (2001) noted that spoken words were symbols of affection and written words were symbols of spoken words. Yule (2006) presented quite a different view of the beginning of language, which was based on the concept of natural sounds. The suggestion was that primitive words could have been imitations of the natural sounds, which early men and women heard around them. Thus, language is one of the natural factors that helps in the advancement of the educational system within any country.

In Pakistan, there is pressure to learn the English language for various purposes. This has happened because of globalization and the continuation of colonial language policies by the government. According to Rahman (2000), though Pakistan is a multilingual country, the English language is considered a symbol of the elite class, power, and sophistication. Rahman (2000) added that recently, in Pakistan, a universal dimension to the teaching and learning of the English language has been added because of an increase in the use of the English language in the global market. Shamim (2011) noted that if we took a quick overview of our history, the need to learn the English language started with the invasion andthe rule of the British in the subcontinent as they wanted to run the machinery of the government with the help of local cheap labor. As their native language was English, they offered all possible encouragement to the local people to study and speak English.Now, the subcontinent is no longer ruled by the British, but we are still in need of the English language in our daily life. The importance of the English language 
cannot be ignored as it has become an international language. Therefore, we need to master it for educational progress as well as for communication with the globalized world.

Hoodbhoy (1998) also added that the present education system in Pakistan was inherited from the pre-partitioned subcontinent. Though we are free to set the goals and line of actions that suit our national interest, we still cannot afford to ignore the fact that people who can speak English can gain greater opportunities. According to Shamim (2011), in Pakistan, English is mainly viewed as a language for individual as well as national development.

Richard (2006) estimated that approximately 400 million people speak English as their first language and a total of 1.5 billion people use English as a second or additional language. The two countries where English is the inherited national language are Britain and the USA but it is also the official language of Australia and New Zealand and one of the official languages of Canada and South Africa. In many other countries, such as India and Nigeria, it is one of the several official languages or the language of business. Because of the importance of English, the learning and teaching of English has become one of the needs of developing countries including Pakistan. Similar to the acquisition of information communication technology (ICT) skills, English language literacy is considered a prerequisite for participation in the global world. Shamim (2011) considered English to be a passport for advancement. It is one of the official languages in Pakistan and has assumed an ever greater significance because of the effects of globalization. Unfortunately, the vast majority of Pakistani students struggle to learn English and the level of the English language proficiency of many university graduates is unsatisfactory. Shamim (2011)pointed out that this was because it is not their first language and they also do not get a chance to speak English in the educational institutions.

According to the UNESCO Seminar in 1953, to teach a language and a civilization is to teach a growing, living subject, which is constantly shifting and changing, and threatening to leave behind people who thought they had once mastered it. Of course English is a global language, and it is spoken every day by politicians and business leaders from all over the world. No matter where people travel, there are English signs and advertisements and in most hotels and restaurants in foreign cities there is an English menu. Unfortunately, many students, especially those in public schools, do not get an opportunity to learn English as they have very little or no exposure to English outside their 30-35 min daily English classes. Shamim (2011) pointed out the higher secondary level was an important stage in an individual's life and it was at this stage that individuals develop a positive outlook and scientific attitude toward life. Therefore, it is essential that by this level students have acquired the skills and are able to apply the knowledge they need to meet the demands of the society. Therefore, they should have enough command of English to easily avail themselves of any opportunity that comes their way. However, as far as colleges are concerned, no importance is given to the learning and teaching of English. In fact the English curriculum at this level has developed according to the needs of the individuals and society.

Shamim (2011) mentioned in the findings of her study that a majority of teachers do not have any formal training or qualifications in the teaching of English and that very limited numbers of teachers are involved in any ongoing professional development activities. Therefore, a large number of students join English language centers to gain a better command of English, so they can pursue higher studies and get a better job in the future and improve their social status. As a result, English language centers are rapidly increasing in Pakistan. The government is also taking steps to promote English and more institutions are being established with both general and specific English language courses being organized for students and teachers. This is particularly important for those teachers teaching at college levelswho are often not proficient enough to fulfill the English language learning and teaching needs of the students.

According to Lawrence (1985), teaching is not to be regarded as a static accomplishment like riding a bicycle or keeping a ledger. Teaching, like all arts of high ambition, is a difficult task. Teaching skills are not acquired without study and diligent practice.

A good teacher can produce positive results regardless of whether the educational system is effective enough to provide better opportunities to the learners. According to Dellor (1996), teachers play an important role in preparing young people to face the future with confidence and contribute to the future society with purpose and responsibility. Therefore, we should train our teachers on how to teach and use the English language with confidence, so that they can easily guide their students to have the English confidence and fluency. In particular, an English language teacher requires more intensive training then their other colleagues in other subjects because English is an important subject. 
According to Azhar F. (1990), if the institutions realize the role that they can play in improving English language teaching (ELT) in Pakistan, they would not be protesting that the teachers need teaching but would start doing something by training the teachers better.

For this purpose, specific courses in the ELT field are conducted by both the private and government sectors and are very necessary and beneficial for those who want to become teachers of English literature or linguistics at secondary or higher secondary level and above, as they can become aware of the language difficulties faced by students, learn effective techniques for better learning, adopt new methodologies and be aware of the latest trends and changes in ELT and learning. Due to the importance of these specific ELT courses, institutions from both the private and government sectors offer diploma, training and degrees. Among such institutions, the Society of Pakistan English Language Teachers (SPELT) foundation is one of the oldest ELT associations and has conducted seminars/workshops/conferences to provide guidance and information about new trends and offered short courses and one or two year specific English Language courses since 1984. The courses offered by SPELT are helpful to English teachers at every level. This is especially true for the Practical Teacher Training Course, as teachers not only become aware of modern methodologies and teaching techniques but also train to conduct activities and drills, through which students are able to gain a functional approach to the English Language.

The SPELT also offers a one year course named ICELT, which stands for In-Service Certificate in English Language Teaching. This course empowers a person with the latest trends, methodologies and strategies to teach English efficiently at all levels. ICELT focuses on language awareness and teaching as well as helping teachers manage and plan teaching and learning aids and develop material. Besides language, teachers also develop assessment and professional abilities. Another institute which was also established in 1984 called the Teacher Resource Centre also offers certificate courses such as the R.S.A. and others to improve ELT.

In the public sector, Karachi University offers an advanced degree program in English Linguistics (i.e., Masters in English Linguistics). In this advanced two year program, eight different courses are included, as shown in the table below:

\begin{tabular}{|c|c|}
\hline Grammar & Phonology \\
\hline TESL & Text Analysis \\
\hline Psycho Linguistics & Lingual Approach \\
\hline Socio Linguistics & Methodology \\
\hline Semantics & Research report \\
\hline
\end{tabular}

In these courses, Teaching English as Second Language is an important course because teachers can polish the four language skills (i.e.,Listening and understanding, reading, writing and speaking) of their students with the help of various activities. This also helps teachers become more innovative while teaching English. Phonology helps to pronounce the words correctly and provides help in understanding the basic rules of learning English.

The A. K. University offers an advanced diploma program in the teaching of English as a foreign language (TEFL) at a higher level. This diploma (TEFL) has been especially designed by "Agha Khan University" to provide participants with a comprehensive understanding of the theoretical and practical foundations of language teaching. The Advance Diploma Program(ADP) offers two types of courses:

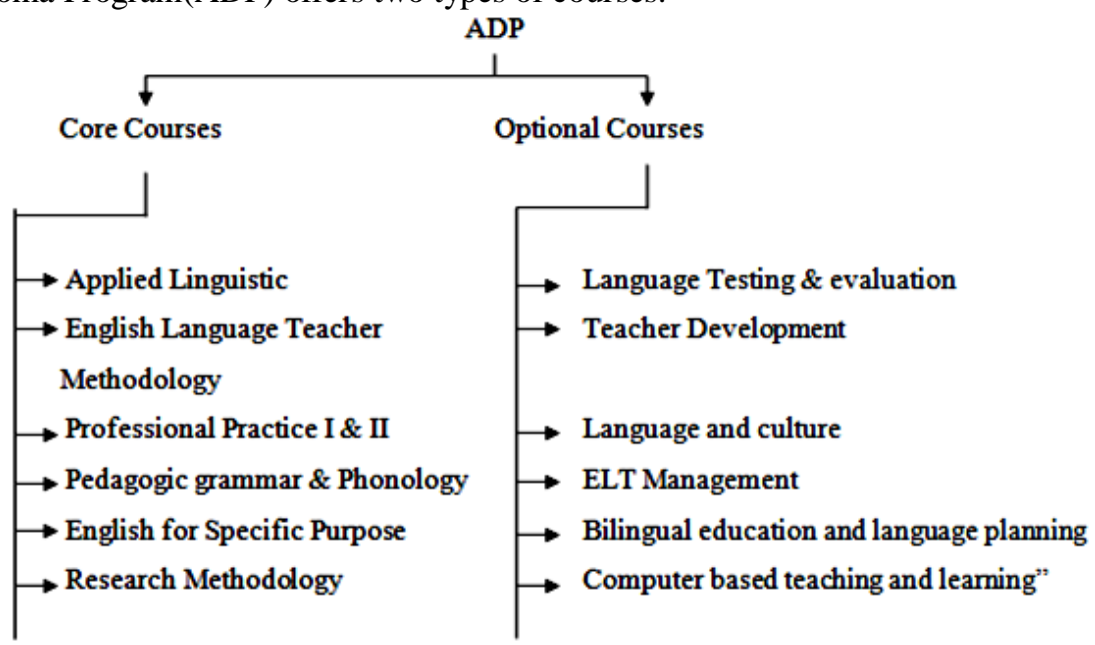


Another institute recognized at the national and international level is the Institute of Educational Development (IED). It not only offers various ELT courses but also conducts and arranges workshops and lectures for improvement in ELT. Through this institution, research is also conducted by individuals at national and international levels, which raises awareness about teaching methodologies, techniques, professional skills, the latest trends and issues in English language teaching-learning. IED has also introduced specific courses for visiting teachers in English, which has eight levels. This course helps teachers polish and enhance the four basic skills through class activities and drills and offers an M.Ed. program consisting of three Modules, i.e.,six week course.

The breakup of the six weeks is:

\begin{tabular}{|c|c|}
\hline First two weeks & English for Academic Purpose \\
\hline Second two weeks & English language teaching \\
\hline Third two weeks & Enhancement of English language \\
\hline
\end{tabular}

Through these modules, they are trained to teach, utilize, and increase their abilities in the field of ELT at every level of learning-teaching. Another basic English language support program has also been introduced which promotes and gives opportunities to English language teachers at the international level through the development of international academic partnerships.

Another institute that is also recognized by HEC and is the only accredited and translation certified university by the foreign embassies is the National University of Modern Languages, Karachi Campus. It offers various ELT courses such as six month certificate and diploma courses, weekend courses of six months (Sundays only), summer short courses of five weeks (during summer vacations) and an M.A. English in Literature and Linguistics + ELT and Linguistics, atwo year ELT-Language program. Classes run in the morning, afternoon and evening. This is the only university in Pakistan which has collaborations and ventures with foreign universities such as Beijing University, China, the International University of Linguistics and Law, Ukraine, University development Franche-Comté (Besancon-Frane), the Agency of international cooperation of the Ministry of foreign affairs, Spain, and the University of Maryland USA. Besides English language, it also offers specific courses in other languages such as Arabic and French.

Some of these institutions establish their own libraries, consisting of literature and books on English language learning. SPELT established their ELT library in 1999 with the assistance of the British Council. It is necessary to establish such libraries in every institute as they would greatly help the teachers and others in updating their knowledge and teaching skills. It is an essential need today to provide training opportunities to our teachers especially English language teachers at every level i.e., primary, secondary, higher secondary or higher level. For this purpose more and more training institutions in the field of ELT should be established to give assistance to English teachers to enhance teaching skills, provide knowledge about the latest research in language teaching, help them adopt new methodologies, techniques theories and activities, and to provide a platform for the promotion of the required language skills.

\section{Objectives of the Study:-}

The objectives of this study were as follows:

1. Bring awareness to concerned teachers about the new issues and trends related to the field of English language and learning.

2. Evaluate the level to which trained teachers utilize the knowledge and skills they receive during their training course.

3. Highlight the importance of special training courses in the teaching of English.

\section{Methodology:-}

The method that was selected and used in this research was the descriptive method. The data was collected through personal observation and a self-developed questionnaire. Within a certain geographical limit, eight government colleges were selected for this study. The sample consisted of a hundred respondents made up of 20 teachers and 80 students. The questionnaire had 30 items for teachers and twenty for students. The collected data was analyzed in tables using a simple percentage and correlation method. Some applicable suggestions were made on the basis of the analyzed data to highlight the importance of specific ELT courses. 
Data Analysis and Interpretation:-

Student Results:-

(Under Training and Untrained Teachers)

Table 1:- The Classroom Environment

\begin{tabular}{|l|c|c|c|c|l|}
\hline \multirow{2}{*}{ Statements } & \multicolumn{2}{|c|}{$\begin{array}{c}\text { Under Training } \\
\text { Teacher }\end{array}$} & \multicolumn{2}{c|}{$\begin{array}{c}\text { Untrained } \\
\text { Teacher }\end{array}$} & \multirow{2}{*}{ Co-relation } \\
\cline { 2 - 5 } & Yes & No & Yes & No & \\
\hline $\begin{array}{l}\text { Teacher maintains discipline in } \\
\text { classroom }\end{array}$ & 40 & 0 & 11 & 29 & Degree : Perfect (1) \\
\cline { 1 - 5 } $\begin{array}{l}\text { English Teacher's attitude toward you } \\
\text { is strict }\end{array}$ & 6 & 34 & 34 & 6 & Direction : Positive \\
\hline $\begin{array}{l}\text { Your Teacher has command over the } \\
\text { English language }\end{array}$ & 40 & 0 & 25 & 15 & Direction : Positive \\
& & & & Degree : Perfect (1) \\
\hline
\end{tabular}

The above table shows that a majority of the students of trained and untrained teachers thought that their teachers maintained discipline in the classroom, showed a strict attitude toward them and had command over the English language.

Table 2:- The Learning Essentials.

\begin{tabular}{|c|c|c|c|c|c|}
\hline \multirow[t]{2}{*}{ Statements } & \multicolumn{2}{|c|}{$\begin{array}{c}\text { Under Training } \\
\text { Teacher }\end{array}$} & \multicolumn{2}{|c|}{$\begin{array}{c}\text { Untrained } \\
\text { Teacher }\end{array}$} & \multirow[t]{2}{*}{ Co-relation } \\
\hline & Yes & No & Yes & No & \\
\hline \multirow{2}{*}{$\begin{array}{l}\text { Your teacher motivates you before } \\
\text { starting the English Lesson }\end{array}$} & \multirow[t]{2}{*}{40} & \multirow[t]{2}{*}{0} & \multirow[t]{2}{*}{7} & \multirow[t]{2}{*}{33} & Degree : Perfect (1) \\
\hline & & & & & Direction : Positive \\
\hline \multirow{2}{*}{$\begin{array}{l}\text { You are satisfied with the teaching } \\
\text { method of your teacher }\end{array}$} & \multirow[t]{2}{*}{37} & \multirow[t]{2}{*}{3} & \multirow[t]{2}{*}{2} & \multirow[t]{2}{*}{38} & Degree : Perfect (1) \\
\hline & & & & & Direction : Positive \\
\hline \multirow{2}{*}{$\begin{array}{l}\text { You feel that your teacher gives you } \\
\text { individual attention }\end{array}$} & \multirow[t]{2}{*}{36} & \multirow[t]{2}{*}{4} & \multirow[t]{2}{*}{3} & \multirow[t]{2}{*}{37} & Degree : Perfect (1) \\
\hline & & & & & Direction : Positive \\
\hline \multirow{2}{*}{$\begin{array}{l}\text { Your teacher uses teaching aids } \\
\text { during teaching }\end{array}$} & \multirow[t]{2}{*}{34} & \multirow[t]{2}{*}{6} & \multirow[t]{2}{*}{2} & \multirow[t]{2}{*}{38} & Degree : Perfect (1) \\
\hline & & & & & Direction : Positive \\
\hline \multirow{2}{*}{$\begin{array}{l}\text { Your teacher's lectures motivate you } \\
\text { to do further reading }\end{array}$} & \multirow[t]{2}{*}{35} & \multirow[t]{2}{*}{5} & \multirow[t]{2}{*}{3} & \multirow[t]{2}{*}{37} & Degree : Perfect (1) \\
\hline & & & & & Direction : Positive \\
\hline
\end{tabular}

The above table shows that a majority of the students of trained and untrained teachers were satisfied with the teaching method, had teachers who motivated them before starting the English lesson, gave them individual attention and used teaching aids during teaching. The teacher's lectures also motivated them to do further reading after the lecture.

Table 3:- Student Personal Views.

\begin{tabular}{|c|c|c|c|c|c|}
\hline \multirow[t]{2}{*}{ Statements } & \multicolumn{2}{|c|}{$\begin{array}{c}\text { Under Training } \\
\text { Teacher }\end{array}$} & \multicolumn{2}{|c|}{$\begin{array}{c}\text { Untrained } \\
\text { Teacher }\end{array}$} & \multirow[t]{2}{*}{ Co-relation } \\
\hline & Yes & No & Yes & No & \\
\hline \multirow{2}{*}{$\begin{array}{l}\text { Any particular student in class who is a } \\
\text { favorite of your teacher }\end{array}$} & \multirow[t]{2}{*}{6} & \multirow[t]{2}{*}{34} & \multirow[t]{2}{*}{21} & \multirow[t]{2}{*}{19} & Degree : Perfect (1) \\
\hline & & & & & Direction : Positive \\
\hline \multirow{2}{*}{$\begin{array}{l}\text { Any particular student in class who is } \\
\text { ignored by your teacher }\end{array}$} & \multirow[t]{2}{*}{0} & \multirow[t]{2}{*}{40} & \multirow[t]{2}{*}{26} & \multirow[t]{2}{*}{14} & Degree : Perfect (1) \\
\hline & & & & & Direction : Positive \\
\hline \multirow{2}{*}{$\begin{array}{l}\text { You attend English compulsory classes } \\
\text { as it is helpful in learning English }\end{array}$} & \multirow[t]{2}{*}{10} & \multirow[t]{2}{*}{30} & \multirow[t]{2}{*}{25} & \multirow[t]{2}{*}{15} & Degree : Perfect (1) \\
\hline & & & & & Direction : Positive \\
\hline \multirow{2}{*}{$\begin{array}{l}\text { You think English classes are helpful } \\
\text { for examinations }\end{array}$} & \multirow[t]{2}{*}{35} & \multirow[t]{2}{*}{5} & \multirow[t]{2}{*}{15} & \multirow[t]{2}{*}{25} & Degree : Perfect (1) \\
\hline & & & & & Direction : Positive \\
\hline
\end{tabular}

The above table shows that a majority of students of the trained and untrained teachers think that some particular students are the teacher's favorite and some students are ignored by the teachers. They also think that English compulsory classes are helpful in learning English as well as from an examination point of view. 
Table 4:- Understanding.

\begin{tabular}{|l|c|c|c|c|l|}
\hline \multicolumn{1}{|c|}{ Statements } & \multicolumn{2}{c|}{$\begin{array}{c}\text { Under Training } \\
\text { Teacher }\end{array}$} & \multicolumn{2}{c|}{$\begin{array}{c}\text { Untrained } \\
\text { Teacher }\end{array}$} & Co-relation \\
\cline { 2 - 5 } & Yes & No & Yes & No & Degree : Perfect (1) \\
\cline { 2 - 5 } $\begin{array}{l}\text { Sometimes hesitates when asking } \\
\text { questions of your teacher }\end{array}$ & 15 & 25 & 38 & 2 & Direction : Positive \\
\hline $\begin{array}{l}\text { Your teacher always satisfies your } \\
\text { question }\end{array}$ & 38 & 2 & 37 & 3 & Degree : Perfect (1) \\
\hline $\begin{array}{l}\text { Your teacher gives you the } \\
\text { opportunity to express yourself }\end{array}$ & 8 & 32 & 38 & 2 & Direction : Positive \\
\hline
\end{tabular}

The above table shows that a majority of the students of trained and untrained teachers think that sometimes they hesitate when asking questions of their teachers if any point/concept is not clear to them but they are always satisfied by the teachers answer. Their teachers also provide students an opportunity to express themselves in class.

Table 5:- Market Value.

\begin{tabular}{|l|c|c|c|c|l|}
\hline \multirow{2}{*}{ Statements } & \multicolumn{2}{c|}{$\begin{array}{c}\text { Under Training } \\
\text { Teacher }\end{array}$} & \multicolumn{2}{|c|}{$\begin{array}{c}\text { Untrained } \\
\text { Teacher }\end{array}$} & \multirow{2}{*}{ Co-relation } \\
\cline { 2 - 5 } & Yes & No & Yes & No & \\
\hline $\begin{array}{l}\text { You need to know English to apply } \\
\text { for a good job }\end{array}$ & 25 & 15 & 20 & 20 & Degree : Perfect (1) \\
\hline $\begin{array}{l}\text { Command over English language } \\
\text { helps to attain better social status }\end{array}$ & 25 & 15 & 24 & 16 & Direction : Positive \\
\hline English is essential for further studies & 24 & 16 & 22 & 18 & Degree : Perfect (1) \\
\cline { 3 - 6 } & & & & Degree : Perfect (1) \\
\cline { 2 - 5 }
\end{tabular}

The above table shows that a majority of the students of trained and untrained teachers think that they need to know and have a command of the English language to apply for good job, to attain a better social status and to do further studies.

Teachers' Results:-

(Trained and Untrained):-

Table 6:- About Instructions

\begin{tabular}{|c|c|c|c|c|c|}
\hline \multirow[t]{2}{*}{ Statements } & \multicolumn{2}{|c|}{$\begin{array}{c}\text { Trained } \\
\text { Teachers }\end{array}$} & \multicolumn{2}{|c|}{$\begin{array}{c}\text { Untrained } \\
\text { Teachers } \\
\end{array}$} & \multirow[t]{2}{*}{ Co-relation } \\
\hline & Yes & No & Yes & No & \\
\hline \multirow{2}{*}{ Believe in proper instruction } & \multirow{2}{*}{10} & \multirow{2}{*}{0} & \multirow{2}{*}{8} & \multirow{2}{*}{2} & Degree : Perfect (1) \\
\hline & & & & & Direction : Positive \\
\hline \multirow{2}{*}{ Instruction should be brief } & \multirow{2}{*}{7} & \multirow{2}{*}{3} & \multirow{2}{*}{3} & \multirow{2}{*}{7} & Degree : Perfect (1) \\
\hline & & & & & Direction : Positive \\
\hline \multirow{2}{*}{$\begin{array}{l}\text { Instruction should be given in English } \\
\text { language }\end{array}$} & \multirow{2}{*}{9} & \multirow{2}{*}{1} & \multirow{2}{*}{4} & \multirow{2}{*}{6} & Degree : Perfect (1) \\
\hline & & & & & Direction : Positive \\
\hline \multirow{2}{*}{ Always need to respect instructions } & \multirow{2}{*}{3} & \multirow{2}{*}{7} & \multirow{2}{*}{6} & \multirow{2}{*}{4} & Degree : Perfect (1) \\
\hline & & & & & Direction : Positive \\
\hline \multirow{2}{*}{$\begin{array}{l}\text { Confident that students will do what is } \\
\text { required }\end{array}$} & \multirow{2}{*}{9} & \multirow{2}{*}{1} & \multirow{2}{*}{6} & \multirow{2}{*}{4} & Degree : Perfect (1) \\
\hline & & & & & Direction : Positive \\
\hline
\end{tabular}

The above table shows that a majority of the trained and untrained teachers believe in proper instructions, and think instructions should be brief and given in English language. They also feel confident that the students will do what is required of them. 
Table 7:- Classroom Teaching.

\begin{tabular}{|c|c|c|c|c|c|}
\hline \multirow[t]{2}{*}{ Statements } & \multicolumn{2}{|c|}{$\begin{array}{c}\text { Trained } \\
\text { Teachers }\end{array}$} & \multicolumn{2}{|c|}{$\begin{array}{c}\text { Untrained } \\
\text { Teachers }\end{array}$} & \multirow[t]{2}{*}{ Co-relation } \\
\hline & Yes & No & Yes & No & \\
\hline \multirow[t]{2}{*}{ Allow student to ask question } & \multirow[t]{2}{*}{10} & \multirow[t]{2}{*}{0} & \multirow[t]{2}{*}{0} & \multirow[t]{2}{*}{10} & Degree : Perfect (1) \\
\hline & & & & & Direction : Positive \\
\hline \multirow{2}{*}{$\begin{array}{l}\text { Correct mistakes/errors of the students } \\
\text { all the time }\end{array}$} & \multirow[t]{2}{*}{2} & \multirow[t]{2}{*}{8} & \multirow[t]{2}{*}{7} & \multirow[t]{2}{*}{3} & Degree : Perfect (1) \\
\hline & & & & & Direction : Positive \\
\hline \multirow{2}{*}{$\begin{array}{l}\text { Students prefer to check understanding } \\
\text { with you }\end{array}$} & \multirow[t]{2}{*}{8} & \multirow[t]{2}{*}{2} & \multirow[t]{2}{*}{3} & \multirow[t]{2}{*}{7} & Degree : Perfect (1) \\
\hline & & & & & Direction : Positive \\
\hline
\end{tabular}

The above table shows that the majority of trained and untrained teachers allow students to ask questions, correct student mistakes/errors of when speaking English all the time and the students prefer to check understanding with the teachers.

Table 8:- Individual Attention.

\begin{tabular}{|l|c|c|c|c|l|}
\hline \multicolumn{1}{|c|}{ Statements } & \multicolumn{2}{c|}{$\begin{array}{c}\text { Trained } \\
\text { Teachers }\end{array}$} & \multicolumn{2}{c|}{$\begin{array}{c}\text { Untrained } \\
\text { Teachers }\end{array}$} & \multirow{2}{*}{ Co-relation } \\
\cline { 2 - 5 } & Yes & No & Yes & No & \\
\hline $\begin{array}{l}\text { Maintain the attention of most } \\
\text { students }\end{array}$ & 8 & 2 & 6 & 4 & Degree : Perfect (1) \\
\cline { 2 - 5 } $\begin{array}{l}\text { While teaching, eye contact is } \\
\text { important }\end{array}$ & 10 & 0 & 6 & 4 & Direction : Positive \\
\hline $\begin{array}{l}\text { During teaching, students need } \\
\text { individual attention }\end{array}$ & 10 & 0 & 3 & 7 & Degree : Perfect (1) \\
\cline { 2 - 5 } & & & & Degree : Perfect (1) \\
\cline { 2 - 5 }
\end{tabular}

The above table shows that a majority of trained and untrained teachers maintain the attention of most students using motivational techniques, think eye contact is important while teaching, and that students need individual attention during teaching.

Table 9:- Teaching Essentials.

\begin{tabular}{|c|c|c|c|c|c|}
\hline \multirow[t]{2}{*}{ Statements } & \multicolumn{2}{|c|}{$\begin{array}{c}\text { Trained } \\
\text { Teachers }\end{array}$} & \multicolumn{2}{|c|}{$\begin{array}{l}\text { Untrained } \\
\text { Teachers }\end{array}$} & \multirow[t]{2}{*}{ Co-relation } \\
\hline & Yes & No & Yes & No & \\
\hline \multirow{2}{*}{$\begin{array}{l}\text { Classroom atmosphere plays an } \\
\text { important role in English language } \\
\text { teaching }\end{array}$} & \multirow[t]{2}{*}{10} & \multirow[t]{2}{*}{0} & \multirow[t]{2}{*}{10} & \multirow[t]{2}{*}{0} & Degree : Perfect (1) \\
\hline & & & & & Direction : Positive \\
\hline \multirow{2}{*}{$\begin{array}{l}\text { Provide enough speaking practice to } \\
\text { students during class }\end{array}$} & \multirow[t]{2}{*}{7} & \multirow[t]{2}{*}{3} & \multirow[t]{2}{*}{3} & \multirow[t]{2}{*}{7} & Degree : Perfect (1) \\
\hline & & & & & Direction : Positive \\
\hline \multirow[t]{2}{*}{ Make use of teaching aids for teaching } & \multirow[t]{2}{*}{7} & \multirow[t]{2}{*}{3} & \multirow[t]{2}{*}{2} & \multirow[t]{2}{*}{8} & Degree : Perfect (1) \\
\hline & & & & & Direction : Positive \\
\hline \multirow[t]{2}{*}{ Make use of pair/group work } & \multirow[t]{2}{*}{10} & \multirow[t]{2}{*}{0} & \multirow[t]{2}{*}{2} & \multirow[t]{2}{*}{8} & Degree : Perfect (1) \\
\hline & & & & & Direction : Positive \\
\hline
\end{tabular}

The above table shows that a majority of trained and untrained teachers think that the classroom atmosphere plays an important role in English language teaching. All feel that they provide enough speaking practice to students, make use of teaching aids and use pair/group work when teaching. 
Table 10:- Training Essentials

\begin{tabular}{|c|c|c|c|c|c|}
\hline \multirow[t]{2}{*}{ Statements } & \multicolumn{2}{|c|}{$\begin{array}{l}\text { Trained } \\
\text { Teachers }\end{array}$} & \multicolumn{2}{|c|}{$\begin{array}{l}\text { Untrained } \\
\text { Teachers }\end{array}$} & \multirow[t]{2}{*}{ Co-relation } \\
\hline & Yes & No & Yes & No & \\
\hline \multirow{2}{*}{$\begin{array}{l}\text { It is necessary for a teacher to prepare } \\
\text { the lesson before delivering }\end{array}$} & \multirow[t]{2}{*}{10} & \multirow[t]{2}{*}{0} & \multirow[t]{2}{*}{10} & \multirow[t]{2}{*}{0} & Degree : Perfect (1) \\
\hline & & & & & Direction : Positive \\
\hline \multirow[t]{2}{*}{ You prefer training base teaching } & \multirow[t]{2}{*}{8} & \multirow[t]{2}{*}{2} & \multirow[t]{2}{*}{3} & \multirow[t]{2}{*}{7} & Degree : Perfect (1) \\
\hline & & & & & Direction : Positive \\
\hline \multirow[t]{2}{*}{ Discuss the lesson with other teachers } & \multirow[t]{2}{*}{10} & \multirow[t]{2}{*}{0} & \multirow[t]{2}{*}{4} & \multirow[t]{2}{*}{6} & Degree : Perfect (1) \\
\hline & & & & & Direction : Positive \\
\hline \multirow[t]{2}{*}{ You are creative and innovative } & \multirow[t]{2}{*}{10} & \multirow[t]{2}{*}{0} & \multirow[t]{2}{*}{7} & \multirow[t]{2}{*}{3} & Degree : Perfect (1) \\
\hline & & & & & Direction : Positive \\
\hline \multirow[t]{2}{*}{ You strictly follow the lesson plan } & \multirow[t]{2}{*}{1} & \multirow[t]{2}{*}{9} & \multirow[t]{2}{*}{7} & \multirow[t]{2}{*}{3} & Degree : Perfect (1) \\
\hline & & & & & Direction : Positive \\
\hline
\end{tabular}

The above table shows that a majority of trained and untrained teachers prepare lesson plans before the class, prefer training baseteaching, but discuss the lesson with other teachers. Most do not strictly follow the lesson plan as they are creative and innovative.

Table 11:- Self Knowledge.

\begin{tabular}{|c|c|c|c|c|c|}
\hline \multirow[t]{2}{*}{ Statements } & \multicolumn{2}{|c|}{$\begin{array}{l}\text { Trained } \\
\text { Teachers }\end{array}$} & \multicolumn{2}{|c|}{$\begin{array}{c}\text { Untrained } \\
\text { Teachers }\end{array}$} & \multirow[t]{2}{*}{ Co-relation } \\
\hline & Yes & No & Yes & No & \\
\hline \multirow[t]{2}{*}{ You visit Libraries very often } & \multirow[t]{2}{*}{9} & \multirow[t]{2}{*}{1} & \multirow[t]{2}{*}{3} & \multirow[t]{2}{*}{7} & Degree : Perfect (1) \\
\hline & & & & & Direction : Positive \\
\hline \multirow{2}{*}{$\begin{array}{l}\text { You have command over the English } \\
\text { language as it is necessary for } \\
\text { communication with the world }\end{array}$} & \multirow[t]{2}{*}{9} & \multirow[t]{2}{*}{1} & \multirow[t]{2}{*}{8} & \multirow[t]{2}{*}{2} & Degree : Perfect (1) \\
\hline & & & & & Direction : Positive \\
\hline \multirow{2}{*}{$\begin{array}{l}\text { You do any special courses you can in } \\
\text { the field of English language teaching }\end{array}$} & \multirow[t]{2}{*}{10} & \multirow[t]{2}{*}{0} & \multirow[t]{2}{*}{0} & \multirow[t]{2}{*}{10} & Degree : Perfect (1) \\
\hline & & & & & Direction : Positive \\
\hline \multirow{2}{*}{$\begin{array}{l}\text { You attend workshops / refresher } \\
\text { courses about English language } \\
\text { teaching }\end{array}$} & \multirow[t]{2}{*}{10} & \multirow[t]{2}{*}{0} & \multirow[t]{2}{*}{7} & \multirow[t]{2}{*}{3} & Degree : Perfect (1) \\
\hline & & & & & Direction : Positive \\
\hline
\end{tabular}

The above table shows that a majority of trained and untrained teachers visit libraries very often, do special courses and attend workshops / refresher courses about English language teaching. They also think that command over English language is necessary in communication with the global world.

Table 12:- Teaching Assessment.

\begin{tabular}{|c|c|c|c|c|c|}
\hline \multirow[t]{2}{*}{ Statements } & \multicolumn{2}{|c|}{$\begin{array}{c}\text { Trained } \\
\text { Teachers }\end{array}$} & \multicolumn{2}{|c|}{$\begin{array}{c}\text { Untrained } \\
\text { Teachers }\end{array}$} & \multirow[t]{2}{*}{ Co-relation } \\
\hline & Yes & No & Yes & No & \\
\hline \multirow[t]{2}{*}{ Feedback is important } & \multirow[t]{2}{*}{10} & \multirow[t]{2}{*}{0} & \multirow[t]{2}{*}{3} & \multirow[t]{2}{*}{7} & Degree : Perfect (1) \\
\hline & & & & & Direction : Positive \\
\hline \multirow{2}{*}{$\begin{array}{l}\text { Feedback helps you to determine the level } \\
\text { of understanding of the students }\end{array}$} & \multirow[t]{2}{*}{10} & \multirow[t]{2}{*}{0} & \multirow[t]{2}{*}{4} & \multirow[t]{2}{*}{6} & Degree : Perfect (1) \\
\hline & & & & & Direction : Positive \\
\hline \multirow{2}{*}{$\begin{array}{l}\text { The higher level English curriculum of } \\
\text { fulfills the required needs of the students }\end{array}$} & \multirow[t]{2}{*}{0} & \multirow[t]{2}{*}{10} & \multirow[t]{2}{*}{0} & \multirow[t]{2}{*}{10} & Degree : Perfect (1) \\
\hline & & & & & Direction : Positive \\
\hline \multirow{2}{*}{$\begin{array}{l}\text { ELT courses are helpful in increasing the } \\
\text { standard of education }\end{array}$} & \multirow[t]{2}{*}{10} & \multirow[t]{2}{*}{0} & \multirow[t]{2}{*}{4} & \multirow[t]{2}{*}{6} & Degree : Perfect (1) \\
\hline & & & & & Direction : Positive \\
\hline
\end{tabular}

The above table shows that a majority of trained and untrained teachers think that feedback is important as it is helpful to determine the level of understanding of the students. They think that the higher level English curriculum 
fulfills the required needs of the students. They feel that ELT courses are helpful in increasing the standard of education.

\section{Conclusions:-}

1. Students of trained teachers reported that their teachers maintained discipline and had a command over the English language, but their attitude was strict.

2. The respondents were also satisfied with the teaching methods and motivational techniques and aids and were confident to ask questions and to express themselves as their teachers gave them opportunities, whereas the students of untrained teachers do not get such opportunities.

3. A majority of the students take English compulsory classes to acquire better jobs and to attain good social status.

4. A majority of the trained and untrained teachers believe in proper instructions though they have to often repeat them, but are confident that the students will do whatever is required by them.

5. Most of the teachers maintained the students' attention by providing speaking practice, giving individual attention, using aids and pair/group work, and maintaining eye contact within the classroom.

6. Both the trained and untrained teachers prepare lectures, have discussions with respective teachers, visit libraries, attend workshops and think feedback is essential to determine the level of understanding of the students.

\section{Recommendations:-}

1. More institutions should be established and organized for the teaching of English language at every level.

2. At college and university level, the medium of instruction should be English because this can make students capable enough to understand English easily and enhance their English language speaking power.

3. To make an individual capable of learning English language skills, specific training courses could be offered for students as well as teachers by both the government and private sectors.

4. To make the educational system better, teachers could be appointed who are not only qualified but also trained to teach the English language.

5. The basic reason for the low ELT standard within our country is that English teachers do not have any formal training in the teaching of languages.

6. In Pakistan, English is one of the major sources of success not only for acquiring higher education but also for gaining better employment. Therefore, many people enroll in ELT centers to develop a full command of the language to further their opportunities.

\section{References:-}

1. Crystal,D. (2003), English as a global Language, Cambridge University Press.

2. Deborah, K.W (2001), Aristotle's Theory of Language and Meaning, Cambridge University Press.

3. Azhar, F. (1990), A Prioritization of Areas of Teaching for ESL Teachers of Pakistan, Lahore Publication.

4. George, Y. (2006), The study of Language, University Press, Cambridge, United Kingdom.

5. Lawrence, S. (1985), Research as a Basic of Teaching, C.E. Merrill Publishing Co.

6. Mooney, A.\& Linda, t. (2010) Language, society and power: An Introduction, Rutledge Madison Ave, New York.

7. Ahmad, N. (1991), Teaching of English as a Second language, Caravan Book House.

8. Hoodbhoy, P. (1998), Education and the state years of Pakistan, Oxford University Press.

9. Hogg, R.\&Devison, D. (2006), History of the English Language, Cambridge University Press.

10. UNESCO (1953) Seminar.

11. Rehman, T. (2000), Language policy, multilingualism and language vitality in Pakistan, Academy of Punjab, North America.

12. Shamim, F (2011), Dreams and Realities: Developing Countries and the English Language, British Council/Design Department/Z413 10 Spring Gardens London SW1A 2BN UK. 